Systematic Parasitology 9: 153-161 (1987)

(C) Dr W. Junk Publishers, Dordrecht - Printed in the Netherlands

\title{
The systematic position of the genus Chirobia Fain, 1959 (Astigmata: Sarcop- tidae) with a description of Chirobia harpyionycteris $n$. sp. from the Old World fruit bat Harpyionycteris whiteheadi (Chiroptera: Pteropodidae)
}

\author{
J.S.H. KLOMPEN and B.M. OCONNOR \\ Museum of Zoology, The University of Michigan, Ann Arbor, MI 48109-1079, USA
}

\section{Summary}

A new species of Chirobia Fain, 1959, C. harpyionycteris n. sp., parasitic on the Old World fruit bat Harpyionycteris whiteheadi (Chiroptera: Pteropodidae) is described and illustrated, with notes on its ecology. The assemblage of the genera Chirobia, Teinocoptes Rodhain, 1923 and Tychosarcoptes Fain, 1976 forms a monophyletic group within the family Sarcoptidae. Within this group, Chirobia is monophyletic, with a sister group relationship between $C$. harpyionycteris and the assemblage of all previously described Chirobia species. The status of Teinocoptes remains uncertain, but the available evidence suggests that this genus may be paraphyletic.

\section{Introduction}

Recent collections of bats from the Philippines made by teams from the University of Michigan, Museum of Zoology (UMMZ), have yielded large numbers of parasitic mites in the family Sarcoptidae. This material allows a review of the systematics and phylogenetic relationships of some of the subgroups in this family. In this paper phylogenetic relationships of the genus Chirobia Fain, 1959 are discussed with reference to a new species, $C$. harpyionycteris $\mathrm{n}$. sp. This species will be described for all life stages, although the association of the male is tentative. The male association is based on the presence of the male on Harpyionycteris whiteheadi (Chiroptera: Pteropodidae), and on the confirmed association of different types of males with the two other sarcoptid species collected from this host, Nycteridocoptes microphallus Fain, 1959 and an undescribed, elongate species of Teinocoptes Rodhain, 1923. To confirm the association, collections of the appropriate moulting stages will be necessary.
The new species is the second one in the Teinocoptes/Chirobia species group to be reported from the Philippines and the first for the main archipelago. Teinocoptes asiaticus Fain \& Domrow, 1961 was reported from the Palawan Islands from Cynopterus brachyotis by Mitchell \& Fain (1963).

The nomenclature for body chaetotaxy used in this paper follows the system of Fain (1963) as adjusted for Chirobia by Klompen et al. (1982). All measurements are in micrometres $(\mu \mathrm{m})$ and presented in tabular form (Table I).

Chirobia harpyionycteris n. sp. (Figs 1-12)

Diagnosis

Described for female, nymphal stages and larva. The association of the described male to this species is tentative. The female differs from all other species in the Teinocoptes/Chirobia group by a combination of the following characters: complete 


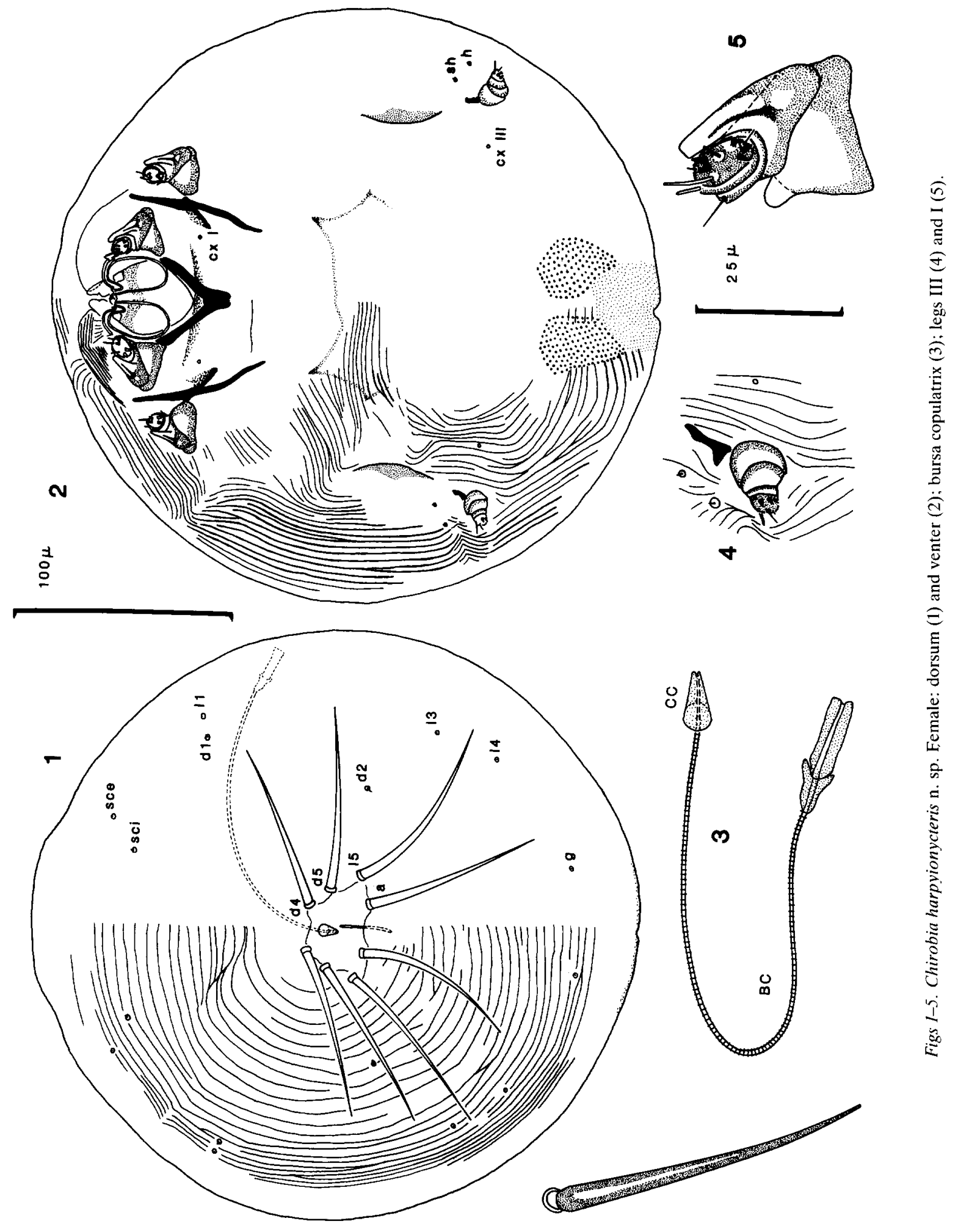


absence of scale-like reticulations of the cuticle, absence of legs IV and the very small size of setae $d_{2}$ and $l_{3}$ (length 1-4). The male can be distinguished from all other males in the group by the presence of numerous triangular scales on the dorsum and the presence of a spinose seta on tibiotarsus IV. The larva is the only one in the genus Chirobia that retains the triangular scales on the dorsum.

\section{Description}

\section{Female (Figs 1-5)}

Idiosoma cone-shaped; base of cone formed by venter. Length of holotype 308, mean for 10 paratypes 308, range 216-378; width 271, mean 296 (216-334). Height less than either length or width.

Dorsum (Fig. 1). Cuticle completely striated; scale-like reticulations or sclerotizations absent. Anus mid-dorsal. Setae $v i$ absent; 4 pairs of circumanal setae $\left(d_{4}, d_{5}, l_{5}, a\right)$, long and tapering, setae $s c i$ and $d_{2}$ short (2-4), setae sce, $d_{1}, l_{1}, l_{3}, l_{4}$ and $g$ minute but present. Bursa copulatrix (BC) long, mean length 143 (132-158); duct ending in welldeveloped copulatory cone (CC), mean length 12 (11-13) (Fig. 3).

Venter (Fig. 2). Striation of cuticle faint or absent in central part of venter, distinct in peripheral parts. Coxal apodemes I confluent; apodemes II long, without antero-lateral protrusions; apodemes III very short. Genital slit not discernable, but genital area delimited by lines that appear to be formed by thickened or double layered cuticle. Resulting structure resembles hexagon, with open posterior side. Two small, crescent-shaped, sclerotized areas present lateral to this structure. Postvulvar area, near midline of body, strongly sclerotized. Setae $h$ and $s h$ minute, sometimes only represented by vestigial alveolus or completely absent; setae $c x I$ and $c x I I I$ absent, or represented by vestigial alveolus. Alveolus of seta $c x I$ observed in only one of 15 females examined. Gnathosoma with chelate chelicerae; system of translucent membranes surrounds gnathosoma completely; subcapitular seta absent.

Legs (Figs 4, 5). Legs I-III poorly developed; legs IV absent. Tarsus and tibia of legs III fused; other segments of legs I-III free. Femora I-II and trochanters I-II with well-developed translucent flaps ventrally. Leg chaetotaxy strongly reduced: trochanteral setae I-III, femoral setae I-II and tibial setae I-II absent; only one filiform seta on genua I-II. Tarsus I-II with 4 spinose and 2 filiform setae and vestigial alveolus of another seta; tibiotarsus III with 2 spinose +3 filiform setae and vestigial alveolus of sixth seta; length of terminal seta on tibiotarsus III not exceeding that of tibiotarsus. Solenidiotaxy simple: genual solenidia sigma-1 and sigma-2 not observed; tibiae I-II and tibiotarsus III with solenidion phi; solenidion omega-1 present on tarsi I-II, solenidion omega-3 on tarsus I. Pretarsi I-II represented by remnants of ambulacral stalk; pretarsus completely absent from tibiotarsus III.

\section{Male (Figs 6-10)}

Only one specimen was available, with length 440 and width 337.

Dorsum (Fig. 6). Propodosomal and hysterosomal shield well sclerotized; separate lateral shields absent although small sclerotized patches present near setae $d_{1}$. Lateral parts of cuticle striated. Central part of podosoma with numerous triangular scales of varying size; patches of small protuberances lateral to setae $v i$, between setae sce and $l_{1}$ and posterior to hysterosomal shield. Anus dorsal. Setae $v i$ long and filiform; setae $d_{1}$ very long (97), all other dorsal setae of moderate length (20-45). Setae $l_{4}$ inserted on the venter.

Venter (Fig. 7). Coxal apodemes I fused to form sternum; apodemes II long, ending free; coxal apodemes III-IV relatively short, with free anterior ends. Podosoma with 4 lightly sclerotized shields, arranged as figured. Total of 12 large, triangular scales irregularly dispersed at posterior edge of propodosomal shield. Some small protuberances present posterior to legs II, at posterior edge of lateral shields and posterior to genital shield. Striations limited to periphery of idiosoma. Aedeagus well sclerotized, posterior to legs IV; genital area covered with sclerotized shield. Setae $l_{4}$ short; coxal setae $(c x I, c x I I I)$ well developed, filiform; setae $h$ and $s h$ filiform, inserted on lateral shields. Genital setae $g_{1}$ and $g_{2}$ present; setae $g_{3}$ 


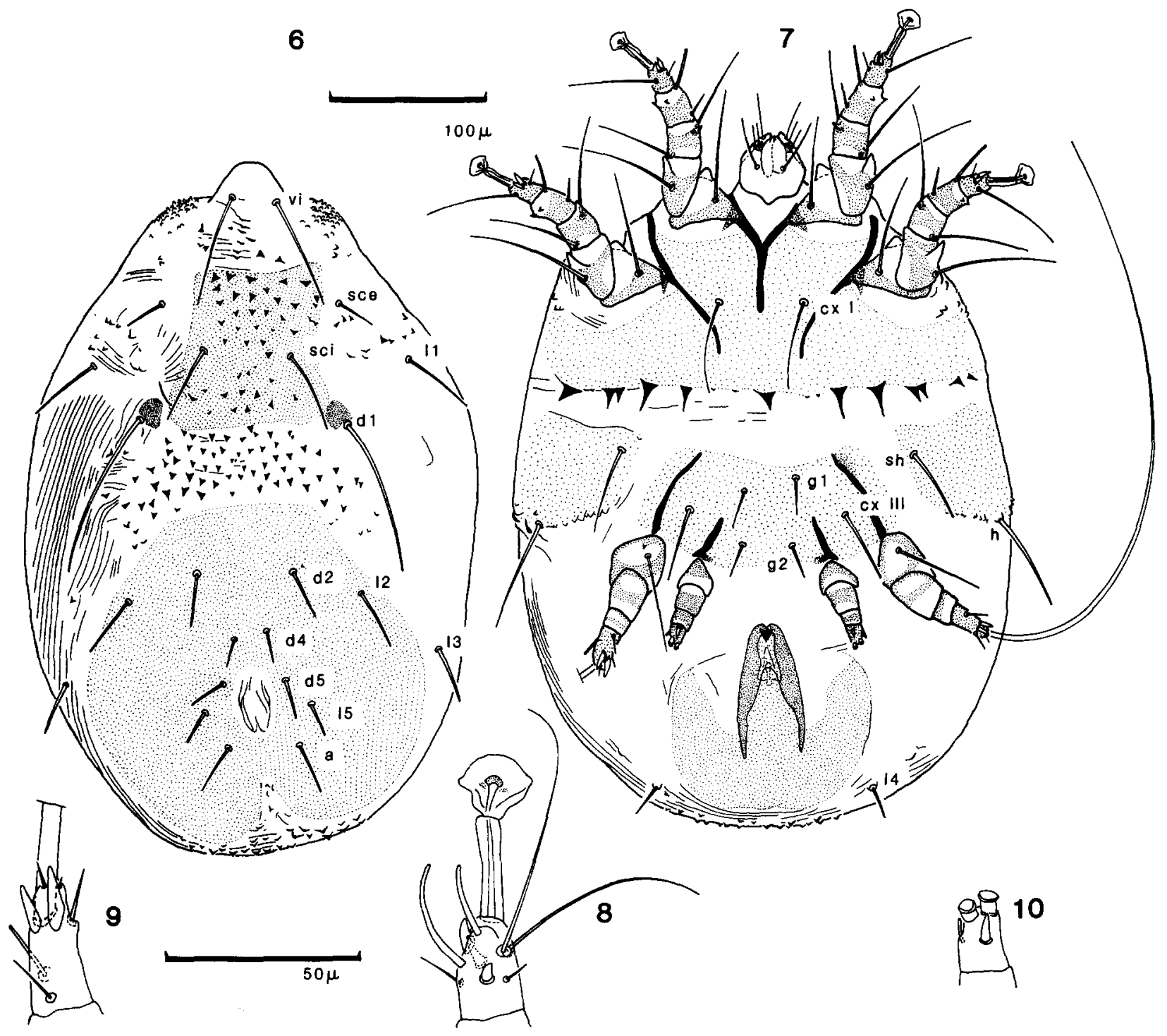

Figs 6-10. Chirobia harpyionycteris n. sp. Male: dorsum (6) and venter (7); tarsus of leg I (8), III (9) and IV (10).

absent. Gnathosoma with chelate chelicerae. Translucent membranes surrounding gnathosoma poorly developed. One pair of subcapitular setae; palps with 3 pairs of setae.

Legs (Figs 8-10). Legs I-III well developed; legs IV reduced. Tibia and tarsus III and IV fused. Femora I-II with ventral spur-like flap. Tibiae I-II ventrally with 2 sclerotized tips, delimiting hollowed distal section (Fig. 7). Chaetotaxy of legs I-III complete for Sarcoptidae. Trochanteral seta
I-III, femoral I-II, both genual setae I-II and tibial seta I-II present. Tarsi I-II with 3 spinose setae, 2 long and 2 short filiform setae (Fig. 8); tibiotarsus III with 2 spinose setae, one long, terminal and 4 short filiform setae (Fig. 9); chaetotaxy of legs IV reduced to one spinose seta and 2 sucker-like setae on tibiotarsus (Fig. 10). Solenidiotaxy as in female, but genual solenidion sigma-1 present on genu I and solenidion phi present on tibiotarsus IV. Pretarsi I-II in form of well-developed ambulacrum; pretarsi of legs III-IV absent. 


\section{Tritonymph}

Idiosomal shape as in female. Mean length of 5 specimens 256 (238-282); width 239 (230-253). Bursa copulatrix, copulatory cone and hexagonal structure in genital area absent. Setae slightly shorter than in female (Table I). Vestigial alveolus of seta $c x I$ present in one of 5 examined tritonymphs. Other characters as in female. Presence of sexual dimorphism in tritonymphs could not be established, since nymphs that could be associated with developing males were not available for this study.

\section{Protonymph}

Idiosomal shape differing from that of female; height exceeding length or width. Length could not be measured accurately since all specimens were oriented laterally on microscope slides. Mean width for 5 specimens 176 (154-196). Compared to tritonymph, protonymph lacks sclerotized postvulvar areas and solenidion omega- 3 on tarsus $I$. All setae shorter than in tritonymph (Table I). Vestigial alveoli of coxal setae (cx l, cx III) not observed in any of 5 examined protonymphs. Other characters as in tritonymph.

Table I. Measurements of Chirobia harpyionycteris $\mathrm{n}$. sp.

\begin{tabular}{|c|c|c|c|c|c|c|c|c|c|c|}
\hline & \multicolumn{3}{|l|}{ Female } & \multirow[t]{2}{*}{ Male } & \multicolumn{2}{|c|}{ Tritonymph } & \multicolumn{2}{|c|}{ Protonymph } & \multicolumn{2}{|l|}{ Larva } \\
\hline & Holotype & $\begin{array}{l}\text { Mean } \\
(\mathrm{N}=10)\end{array}$ & Range & & $\begin{array}{l}\text { Mean } \\
(\mathrm{N}=5)\end{array}$ & Range & $\begin{array}{l}\text { Mean } \\
(\mathrm{N}=5)\end{array}$ & Range & $\begin{array}{l}\text { Mean } \\
(N=5)\end{array}$ & Range \\
\hline Total length & 308 & 308 & $216-378$ & 440 & 256 & $238-282$ & - & - & 114 & $101-121$ \\
\hline Total width & 271 & 296 & $216-334$ & 337 & 239 & $230-253$ & 176 & $154-196$ & 90 & $79-99$ \\
\hline Length leg I & 24 & 25 & $22-29$ & 114 & 22 & $22-24$ & 19 & $15-22$ & 26 & $23-29$ \\
\hline Length leg II & 22 & 22 & $20-24$ & 117 & 19 & $18-20$ & 15 & $13-18$ & 26 & $24-28$ \\
\hline Length leg III & 15 & 15 & $13-18$ & 92 & 13 & $11-13$ & 8 & $9-11$ & 19 & $1.5-22$ \\
\hline Length leg IV & & & & 57 & & & & & & \\
\hline Seta $v i$ & & & & 73 & & & & & 6 & $5-7$ \\
\hline Seta $s c i$ & 3 & 4 & $3-4$ & 25 & 4 & $3-4$ & 3 & $2-3$ & 1 & $1-2$ \\
\hline Seta sce & 1 & 1 & 1 & 52 & 1 & 1 & 1 & 1 & 12 & $9-14$ \\
\hline Seta $d_{1}$ & 1 & 1 & $1-3$ & 97 & 1 & $1-2$ & 1 & $1-2$ & 11 & $10-11$ \\
\hline Seta $d_{2}$ & 3 & 3 & $2-4$ & 33 & 2 & $1-4$ & 2 & $2-3$ & 7 & $6-9$ \\
\hline Setat $d_{4}$ & 75 & 77 & $74-86$ & 20 & 53 & $48-58$ & 36 & $26-44$ & 6 & $5-7$ \\
\hline Seta $d$ & 80 & 76 & $70-80$ & 25 & 53 & $46-61$ & 40 & $31-47$ & 7 & $6-8$ \\
\hline Seta $l_{1}$ & 1 & 1 & $1-2$ & 45 & 1 & 1 & 1 & $1-2$ & 1 & $1-2$ \\
\hline Seta $l_{2}$ & & & & 38 & & & & & & \\
\hline Seta $l_{3}$ & 1 & 1 & $1-2$ & 31 & 1 & 1 & 1 & $1-2$ & 5 & 46 \\
\hline Seta $l_{+}$ & 1 & 1 & 1 & 19 & 1 & 1 & 1 & 1 & 4 & $3-4$ \\
\hline Seta $l_{5}$ & 77 & 74 & $68-78$ & 25 & 54 & $49-58$ & 35 & $27-40$ & 5 & $4-5$ \\
\hline Seta $a$ & 73 & 72 & $67-77$ & 34 & 50 & $44-55$ & 31 & $24-38$ & & \\
\hline Scta $h$ & 1 & v/a & $0-1$ & 81 & v/a & & $v / a$ & & & \\
\hline Seta $s h$ & 1 & v/a & $0-1$ & 54 & $\mathrm{v} / \mathrm{a}$ & & $v / a$ & & 4 & $3-4$ \\
\hline Seta $g$ & 1 & 1 & 1 & & 1 & 1 & 1 & 1 & & \\
\hline Seta $g_{1}$ & & & & 22 & & & & & & \\
\hline Seta $g_{2}$ & & & & 24 & & & & & & \\
\hline Seta $c x I$ & $\mathrm{v}$ & v/a & & 55 & $\mathrm{v} / \mathrm{a}$ & & $\mathrm{v} / \mathrm{a}$ & & 9 & $8-10$ \\
\hline Seta $c x I I I$ & $\mathrm{v}$ & v/a & & 46 & $\mathrm{v} / \mathrm{a}$ & & $\mathrm{v} / \mathrm{a}$ & & 9 & $8-10$ \\
\hline Bursa copulatrix & 143 & 143 & $132-158$ & & & & & & & \\
\hline Copulatory cone & - & 12 & $11-13$ & & & & & & & \\
\hline
\end{tabular}

$\mathrm{v}=$ vestigial alveolus; $\mathrm{a}=\mathrm{absent}$ 


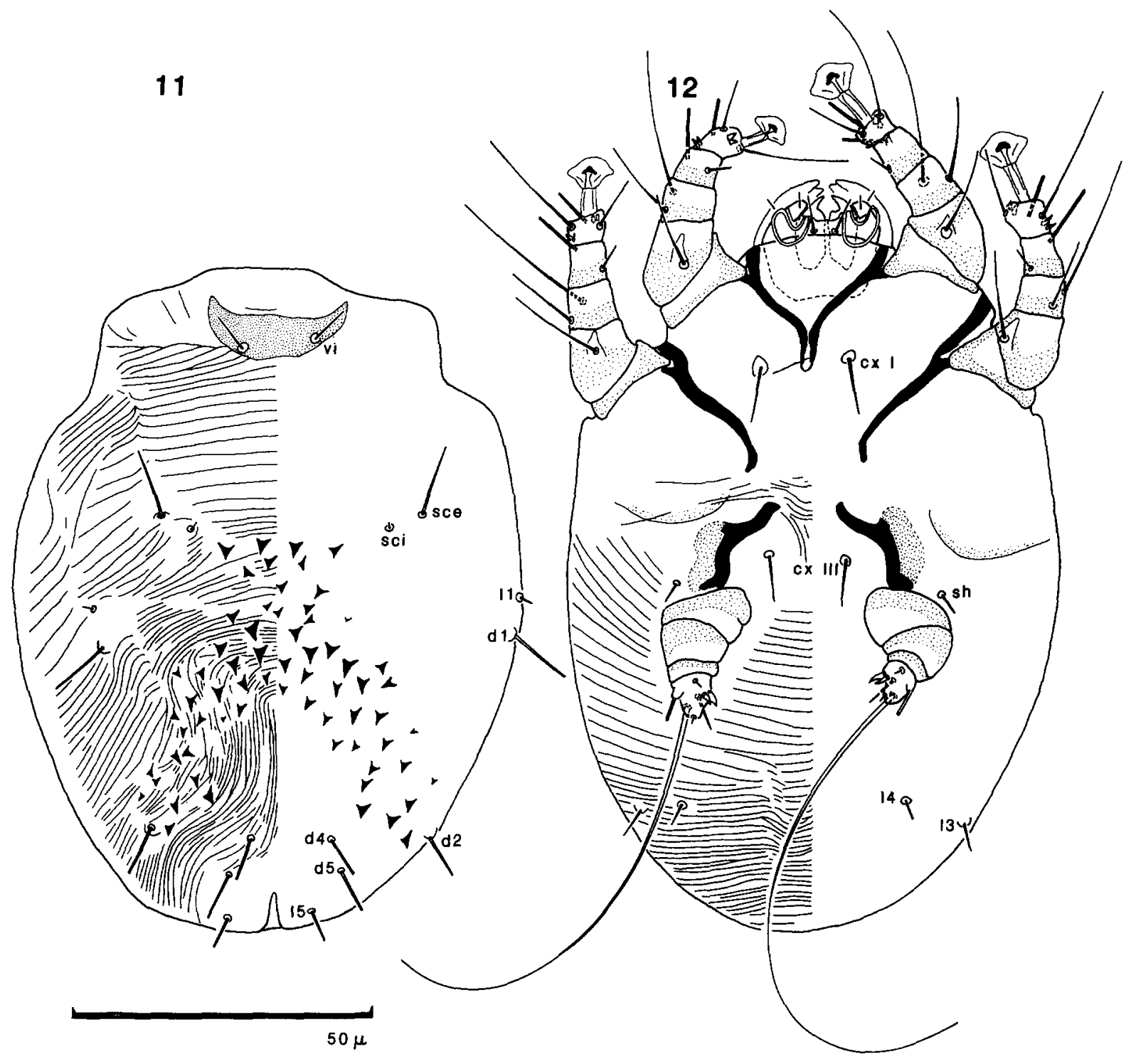

Figs 11-12. Chirobia harpyionycteris n. sp. Larva: dorsum (11) and venter (12).

\section{Larva (Figs 11, 12)}

Mean length for 5 specimens 114 (101-121); width 90 (79-99).

\section{Dorsum (Fig. 11)}

Cuticle completely striated, with exception of extreme anterior parts. About 70 triangular scales form pattern, somewhat resembling inverted ' $\mathrm{Y}$ ', with base between setae $s c i$ and branches ending near setae $d_{2}$. Anus dorso-terminal. Setae vi pres- ent, inserted on small sclerotized shield; 3 pairs of circumanal setae $\left(d_{4}, d_{5}, l_{5}\right)$ of moderate length (4-10), with pointed tips; setae $s c i$ and $l_{1}$ minute (1-2); all other dorsal setae (sce, $d_{1}, d_{2}$ ) filiform with pointed tips; setae $l_{3}$ and $l_{4}$ ventral in position.

Venter (Fig. 12)

Opisthosoma densely striated; podosoma almost bare. Coxal apodemes I touching but not fused; apodemes II long; apodemes III with short anterior bifurcation. Setae $l_{4}$ short; setae $l_{3}$ slightly longer; 
coxal setae (cx I, cx III) well developed, filiform; setae $s h$ short; setae $h, a$ and $g$ absent. Gnathosoma as in female, but system of translucent membranes less well developed. Pair of subcapitular setae present.

Legs. Legs well developed; chaetotaxy more complete than in female: femora and tibiae I-II with one, genua I-II with 2 filiform setae. Tarsi I-II with 4 spinose and 2 long, filiform setae; tibiotarsus III with 2 spinose setae, one very long terminal seta (mean length 94 (85-101)) and 3 short, filiform setae. Solenidiotaxy as in protonymph. Pretarsi of legs I-II in the form of well-developed ambulacra.

\section{Egg}

Mean length of 16 eggs measured 154 (130-180); mean width 97 (77-123). Number of eggs per female never exceeded 3 with only one embryonated.

\section{Type-data}

Holotype female and 2 paratype females ex Harpyionycteris whiteheadi Thomas, 1896 (Chiroptera: Pteropodidae), Philippines: Negros Oriental Prov., Lake Balinsasayao $\left(9^{\circ} 22^{\prime} \mathrm{N}, 123^{\circ} 11^{\prime} \mathrm{E}\right)$, 1-IX-1982, P.D. Heideman. Host in collection of the University of Michigan, Museum of Zoology (UMMZ), Nr. 162375. Additional paratypes from the same host species, Philippines: Negros Oriental Prov., Lake Balinsasayao, 28-VIII-1982, P.D. Heideman, host in UMMZ Nr. 158903 (4 females, one larva): same locality, 4-X-1982, P.D. Heideman, collector nr. PDH 921 (12 females, 2 tritonymphs, 7 larvae); same locality, 8-II-1984, R.B. Utzurrum, host in UMMZ Nr. 161302 (3 females, 6 tritonymphs, 5 protonymphs, 4 larvae); same host species, Philippines: Leyte Prov., Leyte Isl. $\left(10^{\circ} 46^{\prime} \mathrm{N}, 124^{\circ} 49^{\prime} \mathrm{E}\right), 24-\mathrm{V}-1984$, L.R. Heaney, host in UMMZ Nr. 161306 (8 females, one male, one tritonymph). Holotype deposited in the collection of the University of Michigan, Museum of Zoology, Ann Arbor, Michigan. Paratypes deposited in collections of the U.S. National Museum of
Natural History, Washington, D.C.; British Museum (Natural History), London; Institut royale des Sciences naturelles, Brussels: Field Museum of Natural History, Chicago, Illinois; Acarology Laboratory, Ohio State University, Columbus, Ohio; Bishop Museum, Honolulu, Hawaii; Rijksmuseum van Natuurlijke Historie, Leiden; Zoologisches Institut und Zoologisches Museum, Hamburg; Museum National d'Histoire Naturelle, Paris; Raffles Collection, National University of Singapore, Singapore; Department of Plant Protection, Visayas State College of Agriculture, Baybay, Leyte, Philippines; and in collection of the authors.

\section{Discussion}

\section{Ecology}

Chirobia harpyionycteris was collected exclusively from Harpyionycteris whiteheadi, although numerous specimens of 11 species of pteropodid bats from the same localities were examined. All stages of this species occur on the wing membranes of the bats, with the largest numbers on the dorsal side. In contrast with other species of Chirobia, Teinocoptes and Nycteridocoptes, which also occur on the wing membranes of pteropodid bats, C. harpyionycteris is often found in the hairy parts of the wing membrane, very close to the body.

Most of the bats examined had been wrapped individually in cheese cloth soon after collection and had been preserved in fluid. This procedure prevents major losses of ectoparasites during subsequent handling of the bats. Therefore, we are able to present some data on the mite populations on these bats. The infestation level for the 17 bats examined was about $60 \%$, with strongly varying population densities. The highest number of mites collected on a single wing was 218 , but despite these relatively high densities, no deleterious effects on the bats were noticed.

Chirobia harpyionycteris often co-occurred with two other species of sarcoptid mites: Nycteridocoptes microphallus Fain, 1959 and an undescribed, elongate species of Teinocoptes. Although all three 
species were found on the wing membranes, they were generally spatially separated: $N$. microphallus on the distal parts of the wing (and in the mouth), and Teinocoptes sp. exclusively on the posterior trailing edge of the wing.

\section{Systematics}

Fain (1959) separated the genera Teinocoptes Rodhain, 1923, and Chirobia Fain, 1959, from the Sarcoptidae and transferred them to a new family, the Teinocoptidae. This division was not accepted by OConnor $(1982,1984)$, who synonymized the two families, recognizing that accepting the Teinocoptidae as a separate family would leave the Sarcoptidae as a paraphyletic group. Within the Teinocoptes/Chirobia group, the discovery of Chirobia harpyionycteris raises some questions concerning the phylogenetic relationships of the taxa currently included in this group. The new species shares characters of both genera following the definitions of Fain (1959). Using Nycteridocoptes as primary outgroup, and the other genera in the subfamily Notoedrinae as secondary outgroups, a phylogenetic analysis of relationships was carried out focusing on the position of the genus Chirobia.

The assemblage of the genera Teinocoptes and Chirobia (Teinocoptidae sensu Fain, 1959) can be hypothesized to form a monophyletic group, based on the following derived character states: in the female and nymphal stages, absence of setae $v i$, reduction of legs IV to one segment or complete absence of legs IV, presence of scale-like reticulations on the cuticle (these reticulations are secondarily lost in some species); in the male, fusion of tibia and tarsus of legs IV and absence of an ambulacrum on tibiotarsus IV; in the larva, by the presence of a short anterior bifurcation of coxal apodemes III. It seems most probable that Tychosarcoptes Fain, 1976, based only on the male, should also be included in this assemblage, since it shares the modifications of legs IV.

Relationships within the Teinocoptes/Chirobia lineage are much less clear. All previously described species of Chirobia may form a monophyletic group characterized by a few shared, derived character states: in the female, nymphal stages and larva strongly elongated coxal apodemes II with a distinct antero-lateral protrusion, and in the female and nymphal stages reduction of legs III to 3 free segments. Chirobia harpyionycteris shares a number of unique derived character states with these species: reduction of the nontarsal leg chaetotaxy to one seta on genua I-II and strong reduction of the coxal apodemes III in the female and nymphal stages, and in the male loss of the connection between the coxal apodemes III and IV. With both Chirobia and Teinocoptes amphiterinon Klompen et al., 1984 it shares the complete absence of legs IV in the female and nymphal stages. It differs from the known Chirobia species in the loss of the scalelike reticulations in all life stages. This character is shared with Teinocoptes domrowi Fain, 1960, T. eidoloni Fain, 1959, T. auricularis Fain, 1959 and $T$. ituriensis Fain, 1967.

The genus Teinocoptes, as currently defined, may not be a natural group. Nearly all of the characters cited in the latest definition (Fain, 1959) are ancestral within the Teinocoptes/Chirobia group: presence of legs IV, short coxal apodemes II and well-developed coxal apodemes III (all for the female). Only a few character states remain that may characterize the genus, or at least large species groups within the genus. All Teinocoptes species show a distinct dorso-ventral elongation of the body in the female and nymphal stages, resulting in a cylindrical body shape. In contrast, the known Chirobia are all cone-shaped, with the height only slightly exceeding the length. In $C$. harpyionycteris the length exceeds the height in at least the female. Secondly, all Teinocoptes females show a series of (usually small) lateral spines (Klompen et al., 1984), but these are also present in females of $\mathrm{Nyc}$ teridocoptes, indicating that their absence in Chirobia including $C$. harpyionycteris) may be the derived condition. A character shared by $C$. harpyionycteris and a number of Teinocoptes species is the presence of postvulvar sclerotizations in the female. However, as with the interpretation of the difference in shape, the available material did not allow polarization of this character, and thus it is not certain whether both conditions are ancestral for the Teinocoptes/Chirobia group or derived for the genus Teinocoptes. 
In view of the available character evidence, as given above, the most parsimonious hypothesis of relationships involves a sister group relationship between $C$. harpyionycteris and the assemblage of all previously described Chirobia species. Pending further studies on relationships in the group, particularly on the possible paraphyletic nature of the genus Teinocoptes, the new species is included in the genus Chirobia.

\section{Acknowledgements}

We would like to thank Dr L.R. Heaney and P.D. Heideman, Museum of Zoology, University of Michigan, for their trouble in preserving the mites on the collected bats and for reviewing the manuscript.

\section{References}

Fain, A. (1959) Les acariens psoriques parasites des chauvessouris. IV. Le genre Teinocoptes Rodhain. Crèation d'une nouvelle famille: Teinocoptidae (Sarcoptiformes). Revue de Zoologie et de Botanique Africaines, 59, 118-136.

Fain, A. (1963) Les acariens producteurs de gale chez les Lemuriens et les Singes avec une étude des Psoroptidae (Sarcoptiformes). Bulletin de l'Institut Royale des Sciences Naturelles de Belgique, 39 (32), 1-125.

Klompen, J.S.H., Lukoschus, F.S., Fain, A. \& Nadchatram, M. (1982) Description of a bat parasite, Chirobia eonycteris $n$. sp. (Acari: Astigmata: Teinocoptidae) from Malaysia. Malayan Nature Journal, 36, 51-59.

Klompen, J.S.H., Lukoschus, F.S., Nadchatram. M. \& Fain, A. (1984) A new species of Teinocoptes (Acari: Astigmata: Teinocoptidae) with a key to the Malaysian species. Tropical Biomedicine, 1, 63-68.

Mitchell, C.J. \& Fain, A. (1963) Descriptions of five new Teinocoptes (Acarina: Sarcoptiformes) with a key to the known species. Pacific Insects, 5, 479-488.

OConnor, B.M. (1982) Astigmata. In: Parker, S.B. (Ed.) Synopsis and classification of living organisms. New York: McGraw-Hill, pp. 146-169.

OConnor, B.M. (1984) Co-evolutionary patterns between Astigmatid mites and primates. In: Griffith, D.A. \& Bowman, C.E. (Eds) Acarology 6, Vol. 1. Chichester: Ellis Horwood Ltd., pp. 186-195.

Accepted for publication 14th April, 1986 